\title{
Anthós
}

\section{Aphorism's Destructive Capacity Towards Logocentric Text in Friedrich Nietzsche's Thus Spake Zarathustra}

Joseph van der Naald Portland State University

Follow this and additional works at: https://pdxscholar.library.pdx.edu/anthos

Part of the Philosophy Commons Let us know how access to this document benefits you.

\section{Recommended Citation}

van der Naald, Joseph (2011) "Aphorism's Destructive Capacity Towards Logocentric Text in Friedrich Nietzsche's Thus Spake Zarathustra," Anthós: Vol. 3: Iss. 1, Article 6.

https://doi.org/10.15760/anthos.2011.41 
May 10th, 2011

Aphorism's Destructive Capacity Towards Logocentric Text in Friedrich Nietzsche's Thus Spake Zarathustra

\section{by Joseph van der Naald}

The "spirit of gravity" and all of its connotations is central to the writings of Friedrich Nietzsche. In Nietzsche's Thus Spake Zarathustra, Zarathustra proclaims that the spirit of gravity is his devil and that it can only be vanquished through laughter. In this explication, I will show that Nietzsche uses intertextual allusion to place this laughter that destroys the spirit of gravity in relation to the words of the character Clytemnestra in Aeschylus' Agamemnon. I will also show that Nietzsche binds this allusion to aphoristic text, thus framing aphorism as a multivalent form of writing that destroys absolute, serious and logocentric notions of truth. I argue that because of this association the reader is forced to read Thus Spake Zarathustra as a parody of the Bible and of logocentric text in order to truly decipher its meaning. In order to work out my thesis, I will first elaborate on what is meant by the spirit of gravity, and laughter as its destroyer, in Thus Spake Zarathustra through a close analysis of a passage in the aphorism "On the Reading and Writing" from the text. I will then explain the intertextual allusion made to Agamemnon and relate the destruction brought about by Clytemnestra in the tragedy to the concept of laughter destroying the spirit of gravity in Nietzsche's text. I will also examine the implications of Nietzsche's connection of destructive and joyous laughter to aphorism as a form of text, and show that this connection symbolizes how aphorism's multiplicitous interpretations destroy serious absolutist notions of truth espoused by religious, philosophical and scientific texts. Lastly, I will examine how this understanding of aphorism opens up difficulties in reading Thus Spake Zarathustra, and argue that the text is meant to be read as a parody of logocentric Christian, philosophical and scientific discourse.

In order to understand the connection Nietzsche draws between proverb, aphorism and moral 
and philosophical seriousness, one must first work out what is meant by the spirit of gravity. In

Nietzsche's Thus Spake Zarathustra, the first mention of the "spirit of gravity" is located in Zarathustra's speech "On Reading and Writing” in the text's First Part. Zarathustra proclaims in this speech that the spirit of gravity is his devil and that it can only be vanquished through laughter. In this passage, Zarathustra equates gravity to somberness, earnestness, depth, and the attitude that "life is hard to bare." Zarathustra states that through the spirit of gravity, "all things fall" and that the opposite of this spirit is the feeling of levity, height, delicateness, happiness, and laughter. Not by wrath is the spirit of gravity vanquished, but only through laughter can one overcome the spirit of seriousness in life, as Zarathustra calls to the reader, "Up, let us kill the spirit of gravity!" Zarathustra also indicates that a defiance of this certain spirit of gravity allows one to stand above all of the world's seriousness, facilitating laughter at everything tragic and sorrowful in life.

This initial mention of the spirit of gravity and laughter is deliberately placed in a passage that begins, as its title suggests, with the problem of reading and interpretation. Zarathustra proclaims in this section, "In the mountains, the shortest way is from peak to peak ... Proverbs should be peaks, and those who are addressed should be great and tall." Nietzsche describes these proverbs as peaks in order to draw a contrast between this form of writing and other "heavier" forms of text that manifest a certain spirit of gravity. This spirit of gravity affecting forms of text alludes to many different concepts that Nietzsche diagnoses as a similar pervasive problem for all religion, science and philosophy. For instance, the word "gravity" can refer to the ancient Roman virtue of gravitas which means dignity, piety and seriousness. Nietzsche frequently plays with this term, however, and often places gravitas in a negative register. For Nietzsche, gravitas represents the Christian and Platonic view of life as worthless and full of suffering, and the seriousness of the pursuit of truth in philosophy and science. It is important, however, to read from all of the other texts in Nietzsche's canon in order to fully explicate all of the connotations Nietzsche works with when he invokes the word gravity. As Nietzsche writes in 
aphorism 8 of The Genealogy of Morals, in order to perform a true exegesis of his texts, the assumption is made, "that people have first read my earlier works without sparing themselves some effort."

In "On the Spirit of Gravity" from Thus Spake Zarathustra, Zarathustra states that the spirit of gravity makes human life seem "heavy" and that this feeling of burden is the result of the love for one's neighbor. The reference to the "love of the neighbor" is a direct allusion to the Gospels of Matthew 22:39. Further on in "On the Spirit of Gravity" Nietzsche makes another allusion to the Gospels of Mark 10:13 - 10:16 when Zarathustra states, "And for this reason one lets the little children come to one, in order to restrain them early on from loving themselves: this is the spirit of gravity's doing." The intertextual allusions to the Gospels of Matthew and Mark are used to draw a direct connection between the spirit of gravity and a Christian understanding of existence. For Nietzsche, both view life as burdensome because of the suffering and tragedy that one experiences in it. The Christian solution to suffering on earth is an afterlife in heaven, where one's worldly agony is redeemed and an adherence to Christian virtues ("love of the neighbor") is rewarded by eternal happiness. Zarathustra instead teaches that one should "love oneself" and that, "only the human being is a heavy burden to himself! This is because he lugs too much that is foreign to him. Like a camel he kneels down and allows himself to be well burdened." For Zarathustra, the virtues that promote a "love of the neighbor" deny a love of the body, devaluing one's life on earth because it contains suffering. Therefore, the "love of oneself" is an embracing of life, despite pain and suffering, which invokes laughter to destroy this spirit of gravitas and stand above the world's "tragic plays and tragic realities."

Nietzsche also presents this theme of levity and laughter in response to the spirit of gravity in the passage "On the Vision and the Riddle." In this speech, Zarathustra recalls a past dream in which a shepherd is being choked by a black snake that has crawled down his throat. Zarathustra persuades the shepherd to bite off the head of the snake, and once the shepherd obeys, "he leaped to his feet. - No longer shepherd, no longer human - a transformed, illuminated, laughing being." The shepherd's 
laughter is invoked in response to the overcoming of the spirit of gravity and is the same inhuman laughter that overcomes Christian moral seriousness and virtue that rejects earthly life.

The spirit of gravity and the laughter that destroys it cannot be thought of in a specifically Christian register, however. The word gravity can also be interpreted as an allusion to Issac Newton's law of universal gravitation. In the same way that Newtonian physics dictates that objects possessing a heavy enough mass must always fall to earth, the spirit of gravity acts as an overbearing force that denys one levity and happiness. For Nietzsche, Newton's law which attempts to explain natural phenomenon through inductive scientific reasoning exemplifies the notion of gravity and gravitas because it necessarily places more value in the seriousness of absolute empirical truth located outside the realm of aesthetics and the physical world.

In The Gay Science and Beyond Good and Evil, Nietzsche attributes seriousness not only to science and Christianity but also to Platonism and Stoicism. Nietzsche even goes so far as to make a direct comparison between Christianity and Platonism, stating that the former is "Platonism for the 'common people'." In the preface to Beyond Good and Evil Nietzsche refers to "Plato's invention of pure spirit and of transcendental goodness" as a dogmatic philosophy whose approach to truth is riddled with, "awful seriousness and clumsy insistence." In The Gay Science aphorism 326, Nietzsche frames theologians and preachers of moral virtues as con-men for positing that life is something difficult to endure. Within this same aphorism Nietzsche also criticizes what he determines to be a similar strain of thought located in Stoic philosophy which treats life as, "painful and burdensome." Through his use of allusion to other concepts associated with the word gravity, Nietzsche extends the spirit of gravity's meaning by taking aim at any world view that places more importance on heavenly ideals or truths located outside of one's worldly existence.

In turn, the inhuman laughter that destroys the spirit of gravity can also be thought of as a force that annihilates value located in any solemn pursuit of absolute philosophical or scientific truth. This 
interpretation of inhuman laughter as a destructive response to seriousness and the spirit of gravity can be seen in many different forms throughout Nietzsche's work, including aphorism 294 of Beyond Good and Evil titled "The Olympian Vice." In this passage, Nietzsche scorns Thomas Hobbes for giving “any thinking person's laughter a bad reputation" when Hobbes proclaimed laughter to be "a nasty infirmity of human nature that any thinking person will endeavor to overcome." Nietzsche goes on to say that even gods laugh, but not in the same way that humans do. In fact, gods "laugh in a new and superhuman fashion - and at the expense of everything serious!" While this aphorism refers to the seriousness and gravity present in the philosophy of Thomas Hobbes, it is also an allusion to John Chrysostom's Homilies on Matthew where he states most famously, "If thou also weep thus, thou art become a follower of thy Lord. Yea, for He also wept, both over Lazarus, and over the city; and touching Judas He was greatly troubled. And this indeed one may often see him do, but nowhere laugh." This aphorism deliberately unites both the Christian conception of a god who openly recognizes the suffering of an earthly life, refusing laughter, and the serious pursuit of philosophical truth embodied in Thomas Hobbes' writings. The aphorism also contrasts the image of Nietzschean god who, unlike Jesus Christ, does laugh, and whose laughter destroys the gravitas of absolute philosophical certainty, and solemn Christian moral truth.

Nietzsche's connection between the laughter which destroys the spirit of gravity and aphorism as a form of text is made in the first half of "On Reading and Writing" where Zarathustra states, "In the mountains the shortest way is from peak to peak, but for that one must have long legs. Proverbs should be peaks, and those who are addressed should be great and tall." The language of going from "peak to peak" is an intertextual allusion to Aeschylus' Greek tragic drama Agamemnon, where the character Clytemnestra tells of the Watchman's news of Troy's destruction at the hands of the Achaeans. This destructive omen of the fall of Troy passes from the Achaean forces abroad back to Argos through a series of fiery beacons located on high peaks lit one after another. Clytemnestra's speech, both 
prophesying the coming destruction of Agamemnon and Cassandra and recalling the signal of Troy's destruction moving from peak to peak, is connected to the notion of the "proverb" and text moving from "peak to peak" in Thus Spake Zarathustra through intertextual allusion. Nietzsche draws this comparison in order to show that both "proverb" and Clytemnestra's words signal destruction. Just as Clytemnestra's words tell of the destruction of the mighty polis of Troy, a symbol of the world of old and decaying values in Aeschylus' tragedy, Nietzsche's proverb is meant to represent the destruction of the spirit of gravity, a symbol of the old and decaying absolutist and logocentric values of Christianity, science and philosophy. Here, as well as in other locations in Nietzsche's writings, the theme of levity in response to the spirit of gravity is reflected in the way Zarathustra claims that the spirit of a text should be located high above the earth, on "peaks," laughing at and destroying the sense of seriousness associated with gravity and absolute truth.

The sort of proverb that Nietzsche envisions in Zarathustra possesses the ability to destroy these old values associated with serious absolute truth by escaping logocentric meaning manifested in Christian, scientific and philosophical texts. Logocentrism in this context is best defined by Jacques Derrida's use of the term in his 1974 Of Grammatology. Derrida defines logocentrism as a "metaphysics of presence" motivated by a bias in Western philosophy to privilege the spoken word over the written word. Derrida posits that Western philosophical thought tends to view the written word as secondary to speech, because writing is seen as merely a representation of spoken word without the immediate presence of a speaker. This metaphysics of presence leads to a desire for what Derrida terms as a "transcendental signified," or a point of authority or meaning outside of the text itself, to account for this absence of a speaker in writing. Examples of commonly invoked transcendental signifieds include the Logos, or word of God, in the Bible or reason and rationality in scientific and philosophical treatises. What is questioned in Derrida's Of Grammatology is whether Western philosophical thought's tendency to ground absolute truth and meaning in a text through a 
transcendental signified is nothing more than a long-standing privileging of a metaphysics of presence. If language is composed of a system of signs, with meanings that are completely arbitrary in relation to the signifiers that represent them, it is essentially this metaphysics of presence that posits any sort of meaning outside of the system of signs in a transcendental signified. Therefore, the elimination of this transcendental signified would leave the reader with what Derrida calls, "limitlessness of play, that is to say ... the destruction of ... the metaphysics of presence."

Without a grounding of absolute truth and meaning outside the world of writing and text, the only point of reference for interpretation the reader possesses is in other signs and texts. As Derrida points out, this elimination of a metaphysics of presence allows for an unlimited amount of interpretation and play when it comes to the analysis of text, because the text's absolute meaning cannot be grounded in a source of authority outside the world of signs and writing. This is precisely the kind of writing that Nietzsche envisions in Thus Spake Zarathustra. Evidence for this interpretation can be seen in Nietzsche's use of intertextual allusion in his comparison of Troy to the spirit of gravity. The use intertextual allusion invites multivalent interpretations of his text through the use of other writings, and also exemplifies the destruction of the spirit of gravity that is represented in the comparison with Clytemnestra's word's signaling the destruction of Troy.

Nietzsche's use of the word "proverb" is significant in that it draws a comparison to the transcription of the spoken word of Jesus Christ in Biblical text. Zarathustra's speeches are described as proverbs because he is said to be speaking in parable, in the same way that the Gospels are collection of proverbs that record the parables of Jesus Christ. An example of this can be seen Mark 7:17 when Jesus' disciples enquire about his "parables" once he has finished speaking to the Pharisees. While Nietzsche describes his writings in Zarathustra as proverb, Nietzsche's other texts would be described as aphoristic. While the textual form of proverb is similar to that of aphorism, as both are intended to communicate truths, the difference between the two is significant for Nietzsche. A Biblical 
proverb is inherently logocentric, as it grounds its meaning in a transcendental signified in the form of the Logos, or word of God. Nietzsche's aphorism is not logocentric because it is equivocal and attempts to destroy absolute and serious truth associated with a transcendental signified. The purpose of using the word proverb, a form of writing, instead of parable, a speech, is to intentionally invoke the Biblical form, yet avoid grounding the text of Zarathustra in another transcendental signified by privileging writing over the act of speech and hence associating it with non-logocentric Nietzschean aphorism. This purposely encourages the continued multivalent interpretation of text that Nietzsche sees as exemplifying his ideal proverb or aphorism.

Although the Nietzschean aphorism as a form of text invites myriad interpretations, it cannot be interpreted without exegesis, careful reading and rumination. Zarathustra states in "On Reading and Writing" that proverb is text that is not meant to be simply "read" but memorized, internalized and recited by heart. Nietzsche expresses this explicitly in aphorism 8 of the preface to The Genealogy of Morals when he states, "people find difficulty in the aphoristic form: this arises from the fact that today this form is not taken seriously enough. An aphorism ... has not been 'deciphered' when it has simply been read; rather, one has to begin its exegesis. ... practice reading as an art.” Just as Zarathustra's ideal reading of proverb demands a more in depth understanding and internalization, the process of reading aphorism through exegesis makes it clear that Nietzsche believes there to be multiple layers to a text; a surface layer whose meaning lies in what the words of the text mean verbatim (a simple reading of the work), and the excavation of the text's underlying meaning which can only be deciphered through critical interpretation and exegesis.

In order, however, to understand the aphorism's destructive capacity through multivalent interpretation one must also attain the correct perspective. Just as Zarathustra speaks of proverbs traveling from "peak to peak" in "On Reading and Writing," the theme of high "peaks" in relation to text occurs elsewhere in Nietzsche's canon, particularly in aphorism 339 in The Gay Science, titled 
"Vita femina." In this aphorism, Nietzsche states:

For seeing the ultimate beauties of a work, no knowledge of good will is sufficient; this requires the rarest of lucky accidents: The clouds that veil these peaks have to lift for once so that we see them glowing in the sun. Not only do we have to stand in precisely the right spot in order to see this, but the unveiling must have been accomplished by our own soul because it needed some external expression and parable, as if it were a matter of having something to hold on to and retain control of itself. But it is so rare for all of this to coincide that I am inclined to believe that the highest peaks of everything good, whether it be a work, a deed, humanity, or nature, have so far remained concealed and veiled from the great majority and even from the best human beings. But what does unveil itself for us, unveils itself for us once only.

The most beautiful aspects of aphorism, these "peaks," are, for Nietzsche, veiled by the surface layer of text. Yet, through critical interpretation and exegesis, the clouds that veil the "glowing" beautiful meaning are removed so that the destructive capacity inherent in the multivalent aphoristic form is revealed. These "clouds" are not simply removed through sheer good will, however. One must be positioned precisely, through the aid of fortuitous circumstance, and with the help of an "external expression and parable" in order to witness aphorism's capacity for destroying the spirit of gravity. When Nietzsche speaks of standing in precisely the right location, what is meant is that one must attain the correct perspective in order to witness the text's potential to act as a destructive force against absolute truth and seriousness. Attaining this perspective requires an external expression or parable that guides the reader and acts as "something to hold on to." For Nietzsche, aphorism is the ideal external expression for unveiling the text's destructive capacity because its very nature demands exegesis. Exegesis grants the reader a perspective allowing one to recognize the multivalency of text and therefore understand that one absolute serious meaning cannot encompass the whole truth behind a work.

The importance of perspective can also be seen in aphorism 380 of The Gay Science titled "'The wanderer' speaks." The aphorism finds Nietzsche making the comparison between a wanderer, who leaves a town to examine the height of its towers, with a proper examination of European morality, for 
which one needs to stand outside of said morality in order to examine it properly. This point outside of European morality is for Nietzsche, "some point beyond good and evil to which one has to rise, climb, or fly - and in the present case at least a point beyond our good and evil, a freedom from everything 'European'." He then questions, however, if it would even be possible for one to actually rise to such a height as to examine the dynamics of European morality. In reply, Nietzsche states, "this may depend on manifold conditions. In the main the question is how light or heavy we are - the problem of our 'specific gravity.' One has to be very light to drive one's will to knowledge into such a distance." In order to see beyond the absolutist notions of truth associated with European morality, one must possess a certain gravity and, in turn, a specific perspective. Those that have the ability to laugh, and thereby destroy the spirit of gravity have gained the perspective necessary to see the multivalent quality of truth in text. Similarly, this perspective allows one to look beyond the fixed notions of good and evil, truth and falsity associated with weighty Christian morality, and scientific and philosophical certainty.

The aphorism for Nietzsche, as text that evokes and can be associated with inhuman laughter, vanquishes seriousness and gravitas because it is a fundamentally different form of text than those that are associated with the spirit of gravity. Nietzsche's conception of aphorism provides layered meaning with multiple interpretations that run counter to the serious pursuit of truth in scientific and philosophical discourse, where meaning in text is logocentric, can be seen in only one true interpretation and is grounded in a single transcendental signified. The aphoristic form's multiplicitous interpretations also call into question rigid conceptions of good and evil posited in the Bible that are fundamental to establishing the Christian moral world view. In order to interpret the aphorism in this fashion, however, and not read it as Christian proverb, one must maintain a specific perspective that allows one to view the text as possessing mutlivalent meaning. While I have shown in this explication the meaning of aphorism for Nietzsche, there still remains the problem of how one should interpret 
Thus Spake Zarathustra. On the surface, the text appears to provide a joyous, life affirming understanding of the world as an alternative to the serious and life denying conception presented by Christian doctrine, philosophers, and scientists. The paradox that faces the reader in Thus Spake Zarathustra, when analyzed through the framework that I have presented, is that the sort of truths that Zarathustra attempts to posit through a diagnosis of the serious Christian world view are presented in the same sort of logocentric Biblical textual form that Nietzsche is critiquing. The desire to take Zarathustra's diagnosis "too seriously," is complicated by its presentation in the form of a series of Biblical proverbs.

Aphorism, as a style of writing that is multiplicitous in meaning, is a problematic way of presenting what seems to be a Biblical style of text, the same style that is meant to signify a certain spirit of gravity. This interpretation of Thus Spake Zarathustra is further complicated by Nietzsche's own reflection on the text in the fourth aphorism of the preface to Ecce Homo. In this passage, Nietzsche speaks directly about Thus Spake Zarathustra stating, 'Here no 'prophet' is speaking, none of those gruesome hybrids of sickness and will to power whom people call founders of religions. ... It is no fanatic that speaks here; this is not "preaching"; no faith is demanded here." One is then left to wonder how to go about deciphering this work when Zarathustra is presented as a prophet and his teachings as prophetic? I would argue that a third interpretation is possible, that of the text as a parody. Evidence for a parodic interpretation is located in select passages of The Gay Science, namely aphorism 342 and aphorism 1 of Nietzsche's "Preface to the Second Edition." "Incipit tragoedia," Latin for "the tragedy begins," is the title of aphorism 342 in The Gay Science, which contains text that is almost identical to the first passage in Thus Spake Zarathustra. "Incipit tragoedia" is referenced in Nietzsche's preface to the second edition when he states, "Alas, it is not only the poets and their beautiful 'lyrical sentiments' on whom the resurrected author has to vent his sarcasm: who knows what victim he is looking for, what monster of material for parody will soon attract him? 'Incipit tragoedia' 
we read at the end of this awesomely aweless book. Beware! Something downright wicked and malicious is announced here: incipit parodia, no doubt." In substituting the word tragoedia in the title of aphorism 342 with parodia, Nietzsche warns the careful reader that Thus Spake Zarathustra is to be read as a parody by announcing the beginning of the text with the words "The parody begins."

Thus Spake Zarathustra is not, however, simply a parody of Biblical text, as its language explicitly suggests. I argue that it is instead a parody of any style of logocentric reading or writing that attempts to posit absolute truths through transcendental signifieds. In this context, joyous laughter can be seen as both an obvious reaction to a parody, as parody is meant to satire through imitation, and as a reaction to the destruction of the gravitas of Christian moral seriousness and philosophical and scientific absolute truth posited in text. Nietzsche presents the text in a Biblical form, invoking a parodic interpretation, in order to point to the problem of logocentric tendencies inherent in Western moral systems and philosophical discourse. In Thus Spake Zarathustra, Nietzsche is attacking the Christian, scientific, and philosophical mind frame that asserts that one can find absolute truth in rationality, logic or faith in God, and communicate these "truths" in a form of written text that is closed to multiple interpretations. Nietzsche's counter to these mind frames and their logocentric approaches to truth is the aphoristic style of writing, because, while the textual form is similar to Christian, scientific, and philosophical text, it is equivocal and not logocentric and does not privilege any one meaning as the absolute truth.

In this explication, I have shown that Friedrich Nietzsche's Thus Spake Zarathustra attaches the concept of inhuman laughter, signaling the destruction of the "spirit of gravity" in Christian morality and scientific and philosophical certainty, to aphorism, a form of text that Nietzsche personally employs throughout his canon. I have argued that the association Nietzsche makes between aphorism and the destruction caused by Clytemnestra, the destruction of Troy signaled by the flaming beacons, and the laughter that destroys the "spirit of gravity," frames aphorism as a form of writing that destroys 
the serious and logocentric conceptions of truth presented in scientific, Biblical, and philosophical text due to the mulitplicity of different interpretations that an aphorism can take. In order to expound my thesis, I have followed four steps: firstly, I elaborated on what is meant by the spirit of gravity, and laughter as its destroyer, in Thus Spake Zarathustra. I then explained the intertextual allusion made to Agamemnon and related the destruction brought about by Clytemnestra in the tragedy to the concept of laughter destroying the spirit of gravity in Nietzsche's text. I have also examined the implications of Nietzsche's connection of destructive and joyous laughter to aphorism as a form of text, and shown that this connection symbolizes how aphorism's multiplicitous interpretations destroy serious absolutist notions of truth espoused by other forms of text. Lastly, I briefly examined the implicit paradox in Thus Spake Zarathustra due to the fact that the text is presented in Biblical and proverbial form, and argued that the book is meant to be read as a parody of logocentric Christian, philosophical and scientific discourse. In examining Thus Spake Zarathustra in this way, I believe that I have carried out the kind of exegesis necessary for the reading of aphorism as Nietzsche envisioned it. This sort of reading banishes, however, any kind of conventional meaning in the text and instead highlights its ability to operate as a destructive device for interpreting long-standing logocentric modes of thought. Thus Spake Zarathustra, therefore, goes far beyond conventional conceptions of philosophy, redefining the way a reader approaches text and understands truth. 
Works Cited

Aeschylus. The Oresteian trilogy, trans. Philip Vellacott. London. Penguin Classics, 1959.

Derrida, Jacques. Of Grammatology, trans. Gayatri Chakravorty Spivak. Baltimore. Johns Hopkins Press. 1974.

Nietzsche, Friedrich. Thus Spoke Zarathustra. Ed. Robert B. Pippen, trans. Adrian Del Caro. Cambridge. Cambridge University Press, 2006.

Nietzsche, Friedrich. Beyond good and evil: prelude to a philosophy of the future, trans. Marion Faber. New York and Oxford. Oxford University Press, USA, 1998.

Nietzsche, Friedrich. On the Genealogy of Morals \& Ecce Homo, trans. Walter Kaufmann. New York. Vintage, 1974.

Nietzsche, Friedrich. The gay science: with a prelude in rhymes and an appendix of songs, trans. Walter Kaufmann. New York. Vintage, 1974. 